Egyptian Journal of Aquatic Biology \& Fisheries

Zoology Department, Faculty of Science,

Ain Shams University, Cairo, Egypt.

ISSN $1110-6131$

Vol. 24(1): $49-63$ (2020)

www.ejabf.journals.ekb.eg

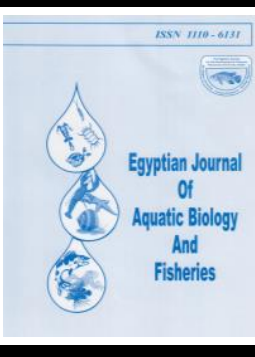

\title{
Accumulation of PCBs and Infections of Parasitic helminthes in Synodontis filamentosus (Boulenger, 1901) and Tilapia zillii (Gervais, 1848) of Epe Lagoon, Lagos, Nigeria
}

\author{
${ }^{2}$ Bamidele Akinsanya, ${ }^{1}$ Patrick Isibor*, ${ }^{2}$ Ademola Emmanuel, ${ }^{3}$ Ebenezer Dada, \\ ${ }^{2}$ Joseph Saliu, and ${ }^{1}$ Grace Olasehinde \\ 1- Department of Biological Science, Covenant University, Ogun State, Nigeria* \\ 2- Department of Zoology, University of Lagos, Nigeria \\ 3- Department of Cell Biology and Genetics,University of Lagos, Nigeria \\ Corresponding Author: patrickisibor007@yahoo.com
}

\section{ARTICLE INFO \\ Article History: \\ Received: Aug. 3, 2019 \\ Accepted: Dec. 27, 2019 \\ Online: Jan. 2020 \\ Keywords: \\ Tilapia zillii \\ Synodontis filamentosus polychlorinated biphenyl bioaccumulation endoparasites}

\section{ABSTRACT}

The study was carried out on 120 Synodontis filamentosus (11 $26.5 \mathrm{~cm}, 22-88 \mathrm{~g})$ and 120 Tilapia zillii $(15-21 \mathrm{~cm}, 67-187 \mathrm{~g})$ captured from Epe Lagoon, Lagos State, Nigeria. The aim was to comparatively analyze the bioaccumulation of polybiphenyl chlorides (PCBs) and prevalence of parasitic helminthes in S. filamentosus and $T$. zillii relative to their respective habits. The comparison was done using indices such as bioaccumulation factors, biota-soil accumulation factors, and parasite prevalence. Profiles of PCB accumulation showed that $T$. zillii followed by their endoparasites accumulated outstanding concentrations, suggesting that $T$. zillii might be a greater bioaccumulator of $\mathrm{PCB}$ s than $S$. filamentosus. Significant biota-soil accumulation factors observed in the $T$. zilliii and their endoparasites were accompanied by significant sorption capacities of PCBs into the soil at impacted locations of the lagoon. This implies that $T$. zillii accumulated significant PCB from the soil and shared with its endoparasites, justifying host-parasite xenobiotic transfer. S. filamentosus had higher levels of parasitic infections than T. zillii, males of both species were more infected than the females. The intestine and liver tissues of $S$. filamentosus showed greater alterations than the tissues of T. zillii. Findings showed that $S$. filamentosus is a better bioindicator in histopathological studies while $T$. zillii is a better bioaccumulator.

\section{INTRODUCTION}

Polychlorinated biphenyls (PCBs) are a class of non-polar toxic chemical compounds consisting of 209 congeners of which only about 130 have been identified in commercial products (Berg et al., 2017). PCBs are used in industrial applications such as hydraulic fluids, lubricants, inks, plasticizers, agrochemicals, etc. from which they leak into soil, surface and underground water (Cappelletti et al., 2015). Discharge of industrial waste into water bodies, and incineration are predominant sources of PCBs in Nigeria (Wang, 2002; Okoh, 2015). Waste management in Epe, Nigeria include land filling, dumping site, and open incineration. These methods are liable to contaminate underground and surface water bodies, thereby gaining access to the aquatic food chain where they are biomagnified up the 
pyramid of biomasses (Moore et al., 2006; Araoye, 2008; Driedger, 2015; Okoh and Daniels, 2016; Isibor and Imoobe, 2017).

Fish contamination by PCBs, particularly in Nigeria has been widely reported (Araoye, 2008; Akinsanya et al., 2015; Driedger, 2015; Okoh and Daniels, 2016). Following contamination, fish tend to undergo some detoxification processes such as depuration through gills, fecal ejection, metabolic transformation and excretion (Paterson et al., 2010). Increase in size as the fish grows may also cause some dilution effects on the ingested xenobiotic. In the case of female fish, reproduction may also represent a significant elimination pathway (Peck et al., 2015).

Bioaccumulation is the increase in concentration of a chemical or xenobiotic in an organism relative to its environment. This is mediated through ingestion, inhalation or absorption (Daley et al., 2009). Fish have high potentials of concentrating considerable amounts of lipophilic compounds from water, sediment and food chain in their tissues (Livingstone et al., 1994; Kaoud and Eldahshan, 2010; Isibor et al., 2016). Sediments act as sink repository for various contaminants in the aquatic ecosystem, and the persistent and non-biodegradable ones such as PCBs may remain in the environment for extended periods (Kumolu-Johnson and Ndimele, 2010).

In ichthyology, eco-morphological studies focus on the interrelatedness of morphometrics (Wainwright \& Richard 1995; O'Grady et al., 2005) such as weight (Angelini and Agostinho, 2005) mouth (Karpouzi \& Stergiou, 2003; Chalkia \& Bobori, 2006; Karachle \& Stergiou, 2011), intestine (Kramer \& Bryant 1995; Karachle \& Stergiou 2010), tail (Karachle \& Stergiou, 2004), and body length of fish, to feeding habits. The indices are used in grouping fishes into fractional trophic levels which may provide some information as to susceptibility of the fish to contaminants and parasitic infections in the environment.

T. zillii is of high economic value in the Epe fish market as it is highly demanded. The fish has preference for shallow areas in a tropical climate and lives over sand, mud, or rock. The principal component of the adult's diet includes chironomid larvae and zooplankton. Supplemental sources are cyanophyte and dinoflagellate algae, periphyton, drifting insects, ostracodes, and porifera (Spataru, 1978; William and Bonner, 2008). Nematodes have also been recovered from the gut of T. zillii (Osho et al., 2016; Adeyemi et al., 2009). Parasites may impact the wellbeing (characterized by low condition factor) of a fish, thereby influencing its feeding habit and diet choice.

In the Epe Lagoon, Syndontis filamentosus is also a commercially significant fish as it is sold in the fish markets in Epe all year round. All members of Syndontis have a structure called a premaxillary toothpad, which is located on the front of the upper jaw of the mouth. This structure contains several rows of short, chisel-shaped teeth. In Syndontis filamentosus, the toothpad forms a short, broad band (Boulenger, 1909). On the lower jaw, or mandible, the teeth of Syndontis are attached to flexible, stalk-like structures and described as "s-shaped" (Cuvier, 1934). Synodontis is the most common genus of the Mochokidae family and of great commercial importance in the inland waters of Nigeria and West Africa (Lalèyè et al., 2006).

High levels of PCBs previously detected in Epe Lagoon have also been linked to discharge of municipal waste into the lagoon (Akinsanya et al., 2015; Akinsanya et al., 2016). Fish in the lagoon, particularly those with high commercial values such as Synodontis filamentosus and Tilapia zillii are liable to bioaccumulate PCBs from the environment, thereby transferring the toxicant to the consumers of the fish. The contaminants may also result in immunosuppression of the fish, further culminating 
in susceptibility to parasitic infections. Health concerns which may ensue from unregulated anthropogenic activities at Epe Lagoon necessitate assessment of PCBs in fishes from the lagoon.

The study aims at comparatively analyzing the bioaccumulation of PCBs and prevalence of parasitic helminthes in Synodontis filamentosus and Tilapia zillii captured from Epe Lagoon. The outcome of the study may contribute to the dearth knowledge of the complex interactions among parasites, hosts and toxicants.

\section{MATERIALS AND METHODS}

\section{Description of study area}

The study was carried out on Epe Lagoon $\left(6^{\circ} 35^{\prime} 2.83^{\prime \prime} \mathrm{N} 3^{\circ} 59^{\prime} 0.10^{\prime \prime} \mathrm{E}\right)$ in Lagos State, Nigeria. It has a surface area of $243 \mathrm{~km}^{2}$. The lagoon is flanked on the sides by two other lagoons; the Lekki Lagoon (freshwater) eastwards and Lagos Lagoons (brackish water) westwards. The lagoon drains into the sea through the Lagos Harbour, within the tropical rainforest belt of southern Nigeria. The seasons include rainy season (May- November), and dry season (December-April). Annual rainfall ranged between 6 to $330 \mathrm{~mm}$ throughout the study period. Riparian vegetation at the bank of the lagoon consists mainly of grasses and secondary rainforest.

Three (3) sampling stations were selected (1 km apart) at strategic locations of anthropogenic perturbation at the lagoon (Fig. 1). The stations were labeled as Stations 1 (Oribo), 2 (Imode) and 3 (Ikosi).

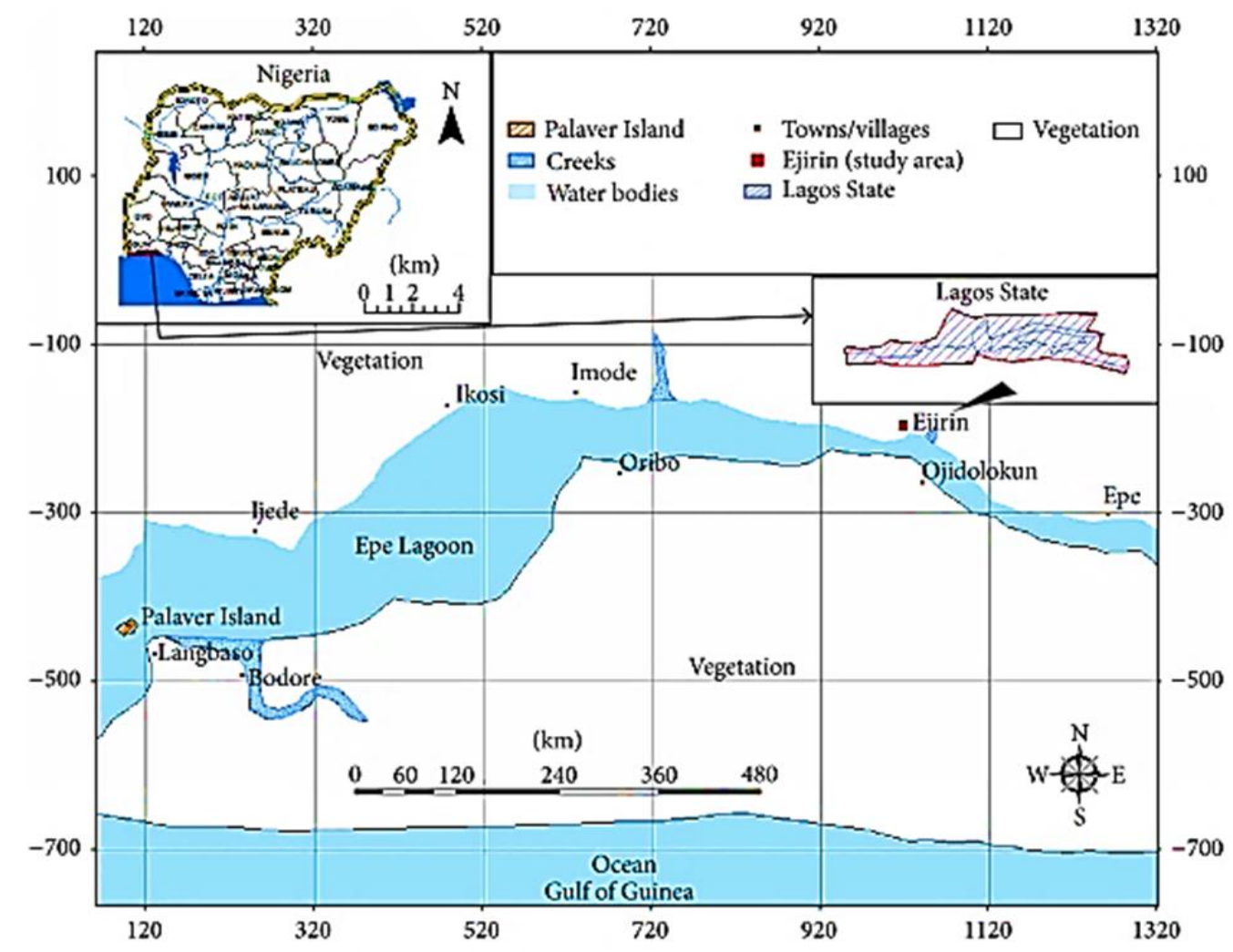

Fig. 1: A map of the study area 


\section{Fish samples}

\section{Collection of fishes}

Synodontis filamentosus and Tilapia zillii were randomly captured at the sampling stations and some were purchased from artisanal fishermen at respective locations between the periods of July- September, 2017. A total of 120 Synodontis filamentosus $(11-26.5 \mathrm{~cm}, 22-88 \mathrm{~g})$ and 120 Tilapia zillii $(15-21 \mathrm{~cm}, 67-187 \mathrm{~g})$. The fish specimens were immediately preserved in an ice-chest with ice blocks prior and transported to the laboratory for analysis.

The sex and maturity of the specimens were determined by gross examination of the gonad and otoliths respectively. The weights were determined to the nearest $0.1 \mathrm{~g}$ using a digital Camry weighing balance (model EK-1A SERIES). The standard lengths and total lengths were recorded to the nearest $0.1 \mathrm{~cm}$ using a meter rule. $S$. filamentosus was identified using the guidelines prescribed by Paugy and Roberts (2003), while T. zillii was identified using descriptions of Williams and Bonner (2008), and Froese and Pauly (2014). The fish individuals were euthanized and the intestines and liverswere eviscerated and persevered in freezer at $-10^{\circ} \mathrm{C}$ prior to further analysis.

\section{Histopathological analysis}

The intestine and liver of infected and uninfected fish specimens were resected for histopathological preparation after dissection. The intestines were stored in Bouin's solution in separate universal bottles for $6 \mathrm{~h}$ and decanted afterwards. $10 \%$ phosphate buffer formalin was added to preserve the intestine and liver tissues. The tissues were grouped into 2 categories namely; heavily infected and non-infected. We randomly selected samples from the preserved tissue from the groups to avoid bias and ascertain quality assurance and control.

The tissues were dehydrated through progressive increase in alcohol concentrations by $1 \%$ at 30 min intervals. Thereafter, the tissues were impregnated in molten paraffin three times and later embedded in molten paraffin wax. Afterwards, the tissues were allowed to solidify. The blocked tissues were sectioned at 4-5 microns, placed into pre-coated slides and allowed to dry. The sections were stained using haematoxylin and eosins (H\&E) stains. The stained tissues were rinsed with distilled water and the excessively stained were rinsed with $1 \%$ acid alcohol to normalize the stain. For microscopic photography, the tissues were dried and mounted under microscope (model BA410E) using DPX mountant. The photomicrographs were taken at the pathology laboratory of the Department in Veterinary Pathology, University of Ibadan, Nigeria.

\section{Analysis of endoparasites}

Intestinal parasites of fish were obtained by evisceration of the intestine using sterile surgical blades according to the guidelines of Akinsanya et al. (2007). The endoparasites were identified morphologically using standard identification keys, in conjunction with pictorial guides provided in manuals such as Colombo et al. (2005), Xing et al. (2005), and Sures (2007). The parasites were fixed in $70 \%$ alcohol, counted and recorded accordingly.

\section{Collection and analysis of water samples}

From the 3 stations, water samples were collected using a sterile $5 \mathrm{~L}$ sampling bottle pre-cleaned with the surface water at each site. The collected samples were then stored in the refrigerator prior to analysis of physiochemical parameters. 
Physicochemical parameters measured in-situ include temperature, using a mercuryin-glass thermometer, while salinity, dissolved oxygen, $\mathrm{pH}$ (hydrogen ion concentration), turbidity, total suspended solids (TSS) and total dissolved solids (TDS) and conductivity were measured using a handheld multi-parameter probe (Horiba Water Checker Model U-10).

\section{Collection and analysis of sediment samples}

The sediment samples were obtained using a Van Veen Grab (5 kg, 15x15 $\mathrm{cm})$. Samples of sediment were collected in polythene bags treated with $10 \%$ nitric acid (Ademoroti, 1996). Salinity, dissolved oxygen, $\mathrm{pH}$, turbidity, total suspended solids (TSS) and total dissolved solids (TDS) and conductivity were measured using a handheld multi-parameter probe (Horiba, Model U-10).

\section{Test for PCBs in environmental media}

Homogenized tissue and parasite samples $(2 \mathrm{~g})$ and $10 \mathrm{~mL}$ water samples were extracted employing column-solid/liquid extraction, using $30 \mathrm{~mL} \mathrm{DCM} / \mathrm{Hex}$ ane $(50 \% \mathrm{v} / \mathrm{v})$ in a glass column of $35 \mathrm{~cm} \times 2 \mathrm{~cm}$. The extract was concentrated to approximately $5 \mathrm{~mL}$ with rotary vacuum evaporator. Analyses were performed with Perkin model 5890 gas chromatograph equipped with Ni 63 electron capture detector.

A low polar HP-5 column of $30 \mathrm{~m}$ length, $0.32 \mathrm{~mm}$ i.d and $0.25 \mathrm{~mm}$ film thickness was used. Nitrogen was used as a carrier gas at a flow rate of flow rate 40 $\mathrm{ml} / \mathrm{s}$. Data were processed using an HP 3396 integrator. PCB congeners in the fish and parasite samples were identified by retention time match with those of the standards. The standard mixture contains PCBs 8, 18, 28, 44, 52, 60, 77, 81, 101, 123, $138,153,156$ and 167 . Hence only these congeners were identified and determined in the samples.

\section{Statistical Analysis}

Statistical analyses were performed on PCBs concentrations in the tested environmental media, which were presented as mean \pm SD per site. One-way ANOVA was used to compare the PCB concentrations in the water, sediment, fish and parasite tissues among the 3 selected stations. Prior to ANOVA the assumption of normality was verified using the Shapiro-Wilk test. Significantly different means were ascertained by post hoc Tukey's HSD test and significance was declared at $\mathrm{P}<$ 0.05 for all analyses.

Bioaccumulation factor (BAF) was calculated thus:

\section{$\mathrm{BAF}=\underline{\text { Concentration of PCB in fish }} \quad$ (Sures et al., 1999) \\ Concentration of PCB in water}

Biota-sediment accumulation factor (BSAF) was calculated thus:

\section{$\mathrm{BAF}=$ Concentration of $\mathrm{PCB}$ in fish Concentration of PCB in sediment}

\section{Quality assurance and quality control}

To ascertain the integrity of data obtained, surrogate analytical grade PCB standards, blanks, replicates, and a certified reference material (CRM) (NMIJ CRM 7404-a, Japan) were adopted in the analysis. The limits of detection (LOD) were 
0.03- $0.41 \mathrm{ng} / \mathrm{kg}$ for water, $0.04-0.32 \mathrm{ng} / \mathrm{kg}$ for sediments, 0.02 to $0.60 \mathrm{ng} / \mathrm{kg}$ for fish, and 0.03 to $0.56 \mathrm{ng} / \mathrm{kg}$ parasites.

\section{RESULTS}

\section{Physicochemistry of environmental media}

The mean values of physicochemical parameters recorded at Stations 1, 2 and 3 respectively were temperature: $26.5 \pm 0.5,25 \pm 0.3,25.2 \pm 0.7 ; \mathrm{pH}: 6.6 \pm 0.1,6.4 \pm 0.3$, $6.5 \pm 0.1$; dissolved oxygen: $4.5 \pm 0.4,3.50 \pm 0.3,3.2 \pm 0.2 \mathrm{mg} / \mathrm{l}$; total suspended solids: $11 \pm 5.5,7.1 \pm 2.6,9 \pm 1.5 \mathrm{~g} / \mathrm{l}$; total dissolved solids: $106.3 \pm 8.4,113.9 \pm 6.3,110.1 \pm 5.6$ $\mathrm{g} / \mathrm{l}$; conductivity: $152.7 \pm 0.5,172.3 \pm 2.6,193.3 \pm 3, \mu \mathrm{S} / \mathrm{cm}$; salinity: $4 \pm 0.5,5 \pm 0.3$, $4.5 \pm 0.5 \mathrm{ppt}$; turbidity: $10.3 \pm 3.5,7.7 \pm 3.2,7.7 \pm 2.5 \mathrm{NTU}$.

All the parameters were within the FEPA (Federal Environmental Protection Agency) standard regulatory limit (Table 1). However, the TSS and Turbidity recorded at Station 1 were significantly higher than other stations, while turbidity at Station 1 was slightly above regulatory limit $(\mathrm{p}<0.05)$.

Table 1: Physicochemical parameters of water

\begin{tabular}{lllll}
\hline PARAMETERS & Station 1 & Station 2 & Station 3 & FEPA (2003) \\
& & & & \\
Temperature $\left({ }^{\circ} \mathrm{C}\right)$ & $26.5 \pm 0.5$ & $25.8 \pm 0.3$ & $25.2 \pm 0.7$ & $<40$ \\
pH & $6.6 \pm 0.1$ & $6.4 \pm 0.3$ & $6.5 \pm 0.1$ & $6-9$ \\
DO $(\mathrm{mg} / \mathrm{L})$ & $4.5 \pm 0.4$ & $3.5 \pm 0.2$ & $3.2 \pm 0.3$ & $>5.0$ \\
TSS $(\mathrm{g} / \mathrm{L})$ & $\mathbf{1 1} \pm \mathbf{5 . 5}$ & $7.1 \pm 2.6$ & $9 \pm 1.5$ & 30 \\
TDS $(\mathrm{g} / \mathrm{L})$ & $106.3 \pm 8.4$ & $113.9 \pm 6.3$ & $110.1 \pm 5.6$ & 2000 \\
Conductivity $(\mu \mathrm{S} / \mathrm{cm})$ & $152.7 \pm 0.5$ & $172.3 \pm 2.6$ & $193.3 \pm 3$ & 400 \\
Salinity $(\mathrm{ppt})$ & $4 \pm 0.5$ & $5 \pm 0.3$ & $4.5 \pm 0.5$ & $\mathrm{NA}$ \\
Turbidity $(\mathrm{NTU})$ & $\mathbf{1 0 . 3} \pm \mathbf{3 . 5}$ & $7.7 \pm 3.2$ & $7.7 \pm 2.5$ & 10 \\
\hline
\end{tabular}

Emboldened figures are significantly higher at $\mathrm{p}<0.05$.

The parasites identified in the infected fishes were Cestodes- Wenyonia spp. and Nematodes- Procamallanus sp. and Raphidascaroides spp. Among t the T. zillii 14 of 107 males, and 8 of 13 females were infected, and total parasite prevalence for males and females were 13.1 and 61.5 respectively (Table 2). Among the $S$. filamentosus on the other hand, 79 of 88 males and 28 of 32 females were infected and the . total parasite prevalence were 89.8 and 87.5 for males and females respectively (Table 2). The overall parasite prevalence in S. filamentosus (117.3) was higher than in T. zillii (74.6). The mean parasite intensity in S. filamentosus was also higher than in $T$. zillii. 
Table 2: Gastrointestinal helminthes infections relative to morphometrics of fish

\begin{tabular}{|c|c|c|c|c|c|c|}
\hline Sex & $\mathrm{SL}(\mathrm{cm})$ & $\mathrm{NE}$ & NI & Prevalence $(\%)$ & Worm load & Mean Intensity \\
\hline \multicolumn{7}{|c|}{ Tilapia zilli } \\
\hline \multirow{3}{*}{ MALE } & $(14.6-16.5)$ & 10 & 2 & 20 & 12 & 6 \\
\hline & $(16.6-19.5)$ & 56 & 4 & 7.1 & 47 & 11.8 \\
\hline & $(19.6-22.5)$ & 41 & 8 & 19.5 & 102 & 12.8 \\
\hline \multirow[t]{2}{*}{ TOTAL } & & 107 & 14 & 13.1 & 326 & 30.6 \\
\hline & $(14.6-16.5)$ & 2 & 2 & 100 & 3 & 1.5 \\
\hline \multirow{2}{*}{ FEMALE } & $(16.6-19.5)$ & 7 & 3 & 42.9 & 5 & 1.7 \\
\hline & $(19.6-22.5)$ & 4 & 3 & 75 & 8 & 2.7 \\
\hline \multirow[t]{3}{*}{ TOTAL } & & 13 & 8 & 61.5 & 140 & 5.9 \\
\hline & \multicolumn{6}{|c|}{ Synodontis filamentosus } \\
\hline & $(11.0-16.5)$ & 4 & 3 & 0.75 & 34 & 11.3 \\
\hline \multirow[t]{2}{*}{ MALE } & $(16.6-21.5)$ & 31 & 30 & 96.8 & 137 & 4.5 \\
\hline & $(21.6-26.5)$ & 56 & 49 & 87.5 & 240 & 4.9 \\
\hline \multirow[t]{2}{*}{ TOTAL } & & 88 & 79 & 89.8 & 377 & 20.7 \\
\hline & $(11.0-16.5)$ & 3 & 3 & 100 & 9 & 3 \\
\hline \multirow[t]{2}{*}{ FEMALE } & (16.6-21.5) & 14 & 13 & 92.9 & 75 & 7.8 \\
\hline & (21.6-26.5) & 17 & 11 & 64.8 & 96 & 8.7 \\
\hline TOTAL & & 32 & 28 & 87.5 & 140 & 19.5 \\
\hline
\end{tabular}

$\mathrm{SL}=$ standard length, $\mathrm{NE}=$ number examined, $\mathrm{NI}=$ number infected

\section{Comparative bioaccumulation}

Analysis of PCB congeners in the parasites recovered from the intestine of $T$. zillii (Fig. 2) revealed outstandingly high concentration of PCB 81 in parasites from Station 1. Fairly high concentrations of PCB 8 were observed in Stations 2 and 3. PCB 81 was outstandingly high in the tissues of T. zillii at Station 3, followed by Station 1 (Fig. 3). Some levels of PCB 28 (Station 2), and PCB 44 (Stations 1 and 2) were also observed in the tissues of $T$. zillii. 


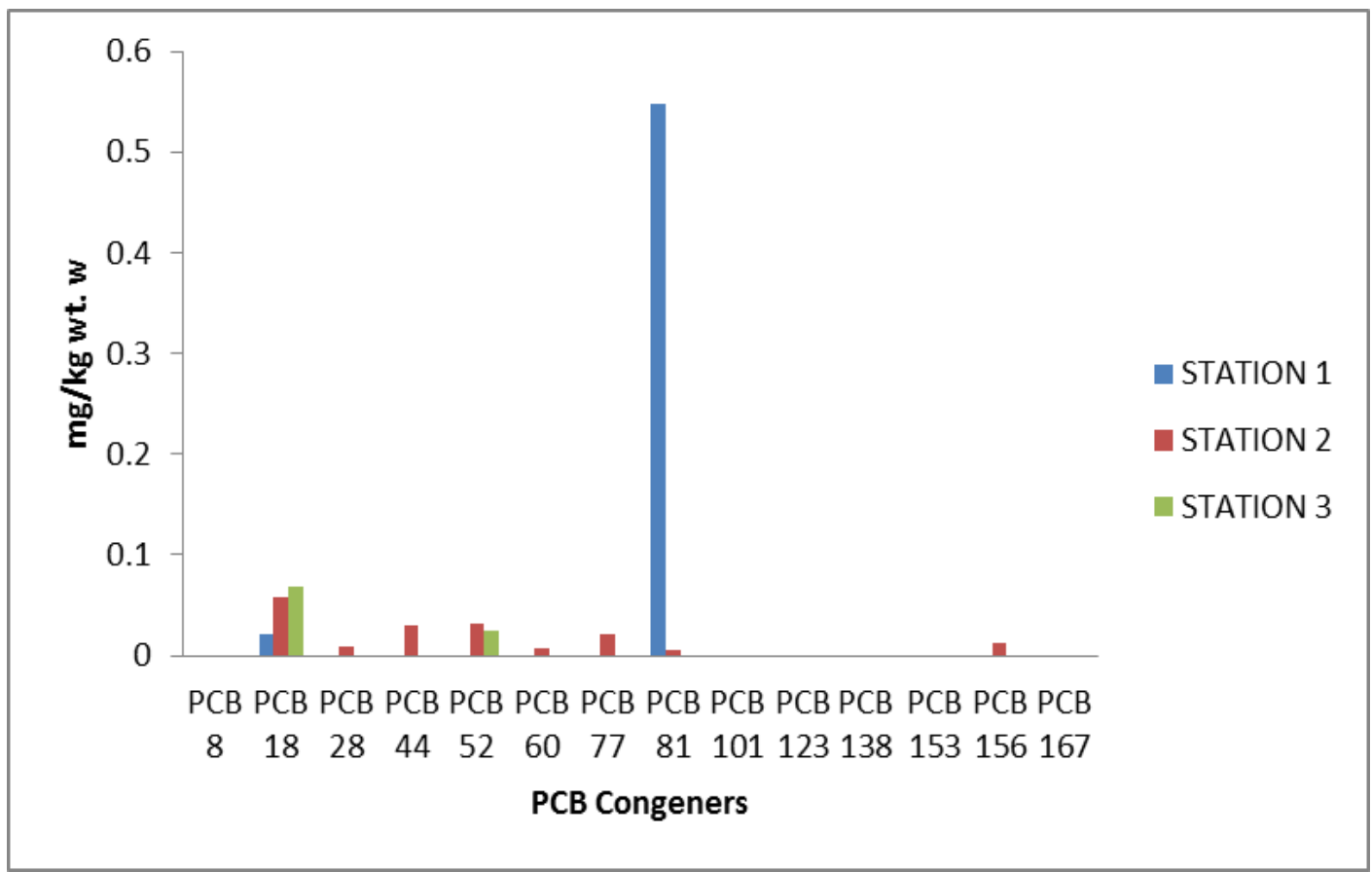

Fig. 2: PCB congeners in Tilapia zillii parasites across stations

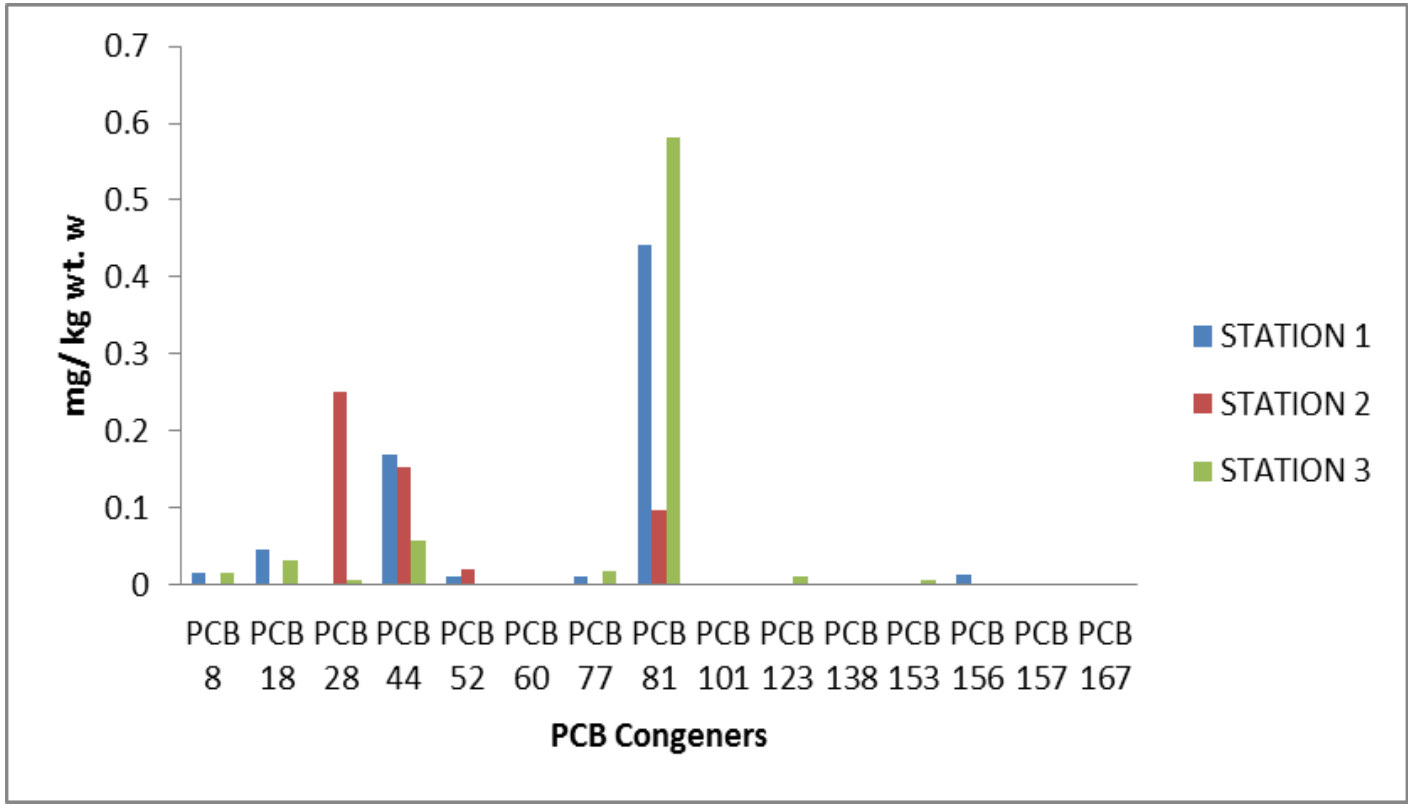

Fig. 3: PCB congeners in the tissues of Tilapia zilli across stations

Most of the PCB congeners detected in the tissues of the parasites were also observed in S. filamentosus. Parasites of S. filamentosus at Station 1 had the highest concentrations of most of the PCB congeners analyzed (Fig. 4). PCB 81 was distinctively high at Station 2 (Fig. 5). 


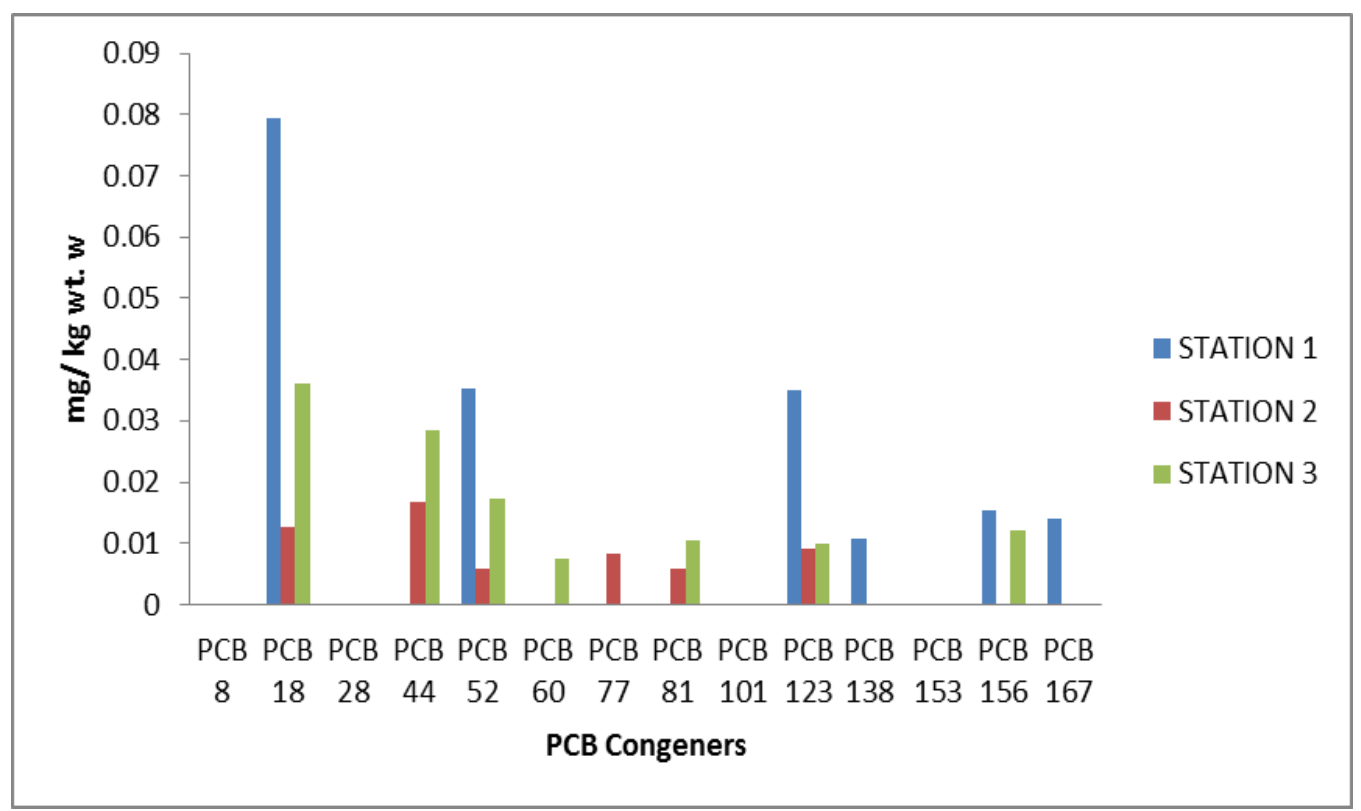

Fig. 4: PCB congeners in Synodontis filamentosus parasites across stations

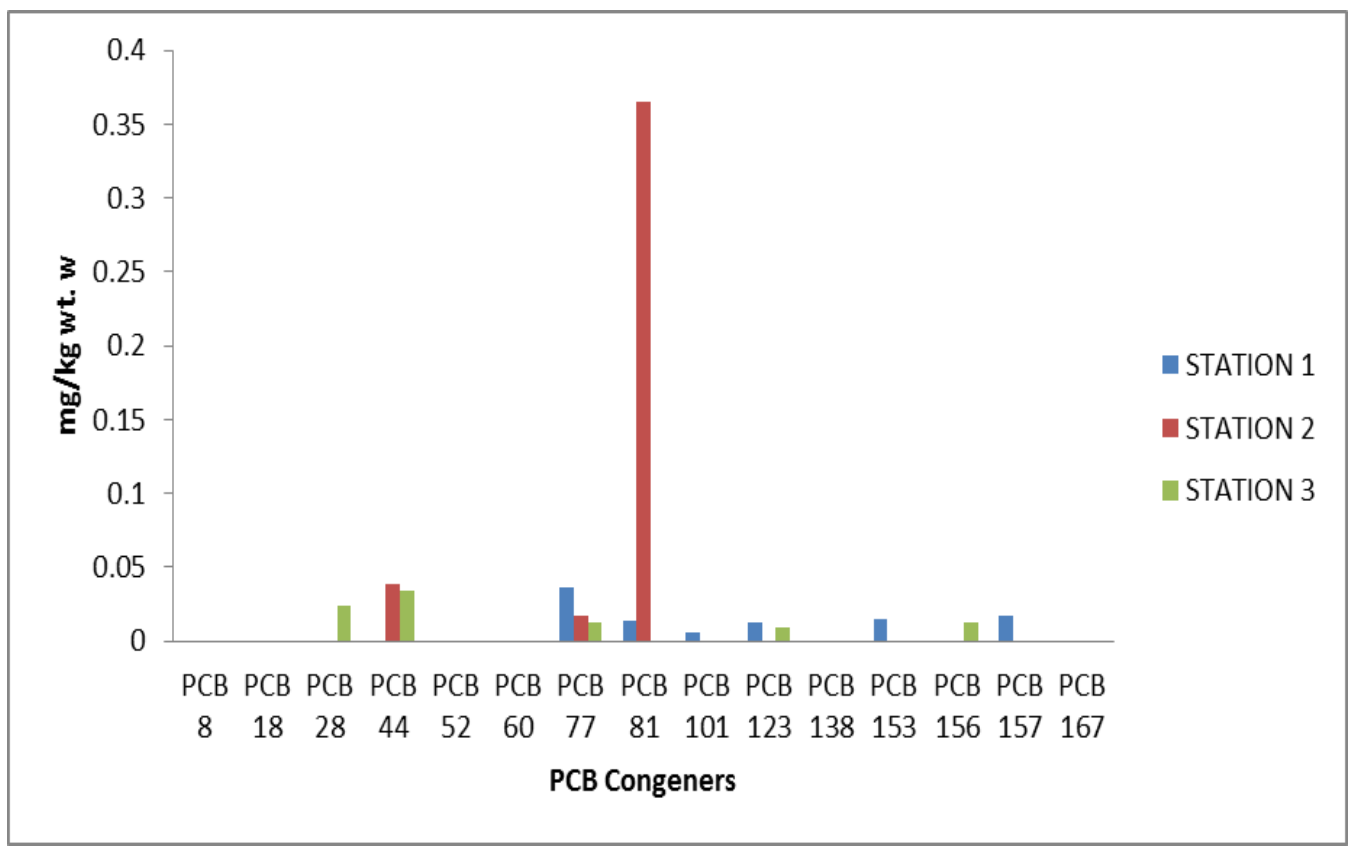

Fig. 5: PCB congeners in the tissue of S. filamentosus across stations

Sediment samples collected at the 3 stations showed distinctively high concentrations of PCB 81; particularly at Station 2 (Fig. 6). In the water concentrations of PCBs 8, 28, 44, and 156 at station 1 was outstandingly higher than the concentrations at other stations (Fig. 7). 


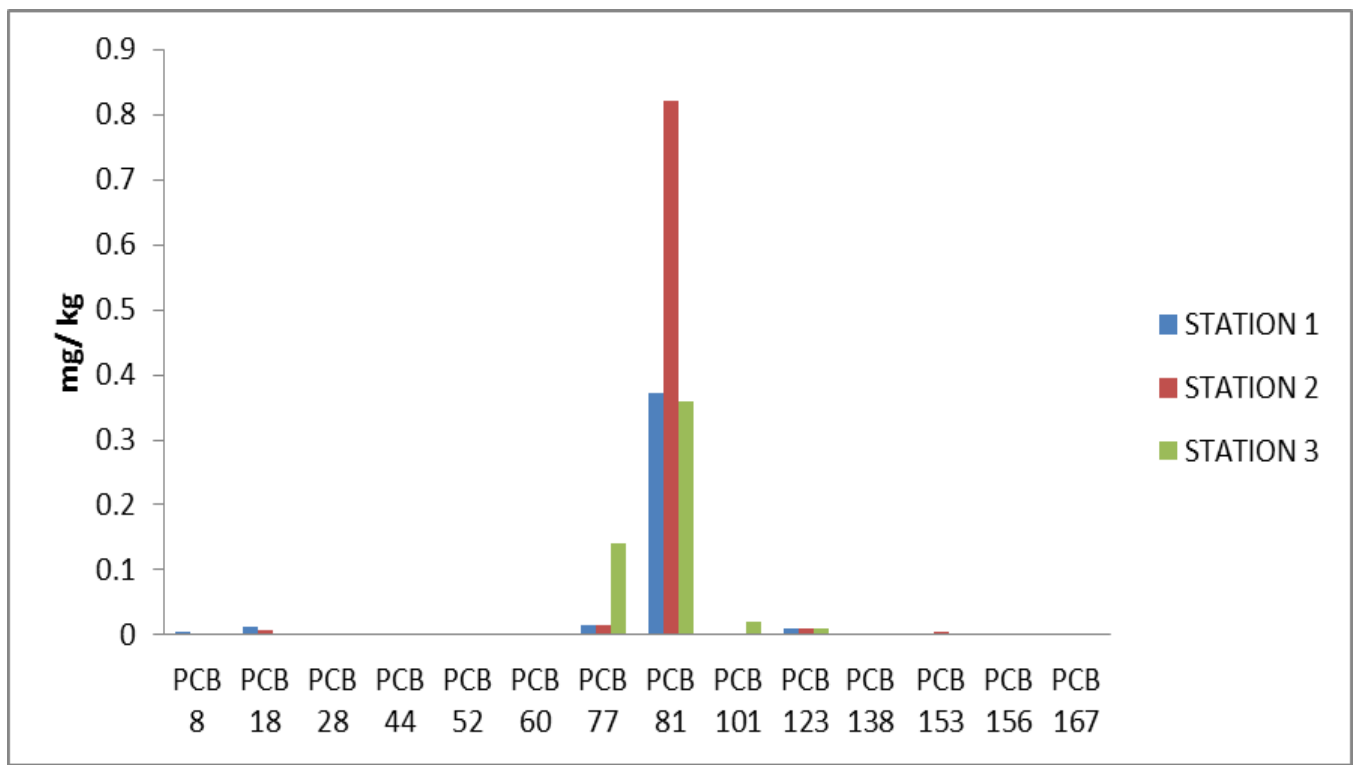

Fig. 6: PCB congeners in sediment samples across stations

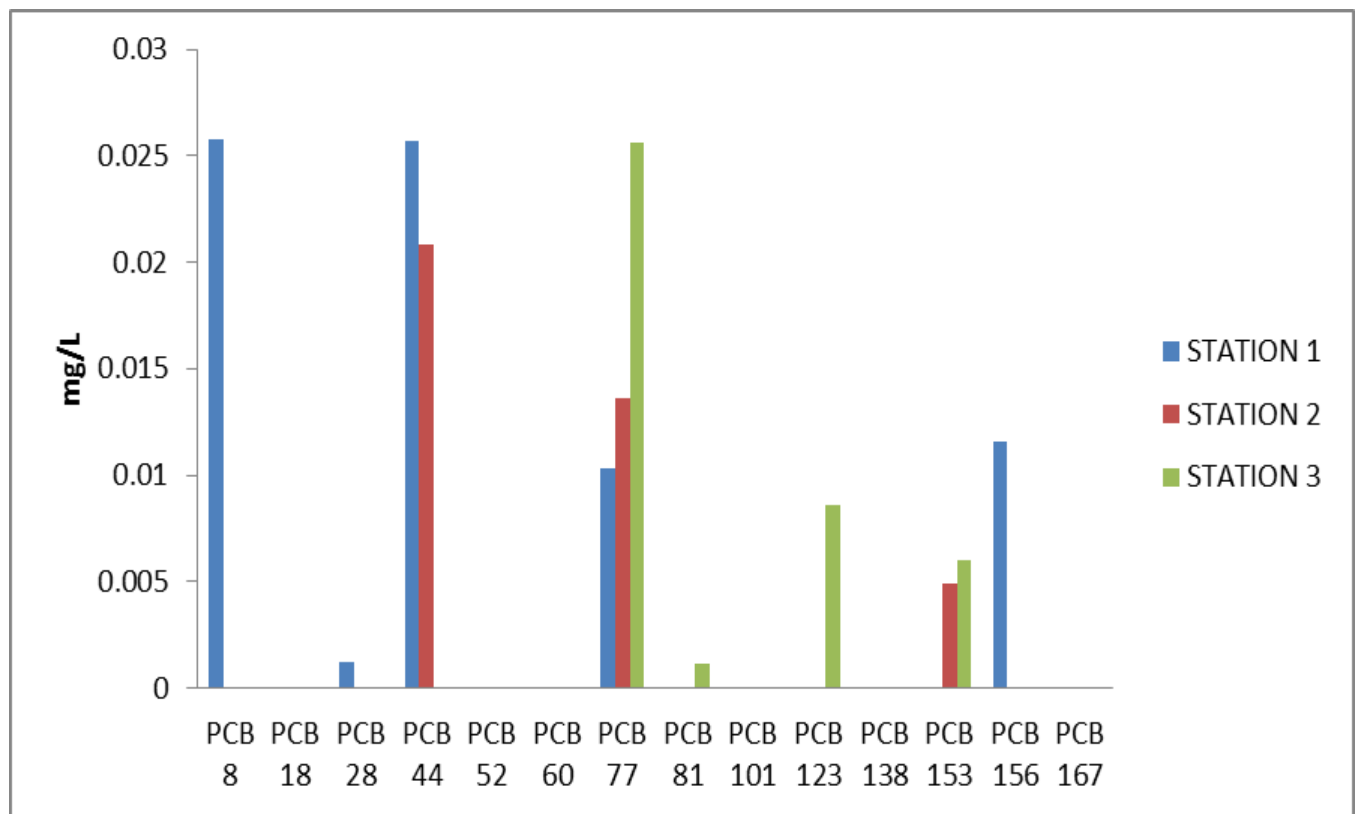

Fig. 7: PCB congeners in water samples across stations

At Station 1, the sequence of PCB accumulation in the environmental media was $T$. zillii $>T$. zillii parasites $>$ sediment $>S$. filamentosus parasites $>S$. filamentosus $>$ water $>$, at Station 2 the sequence was sediment $>$ T. zillii $>S$. filamentosus $>$ T. zillii parasites $>$ S. filamentosus parasites $>$ water, while at Station 3 the sequence was $T$. zillii $>$ sediment $>S$. filamentosus parasites $>T$. zillii parasites $>$ S. filamentosus $>$ water (Fig. 8). 


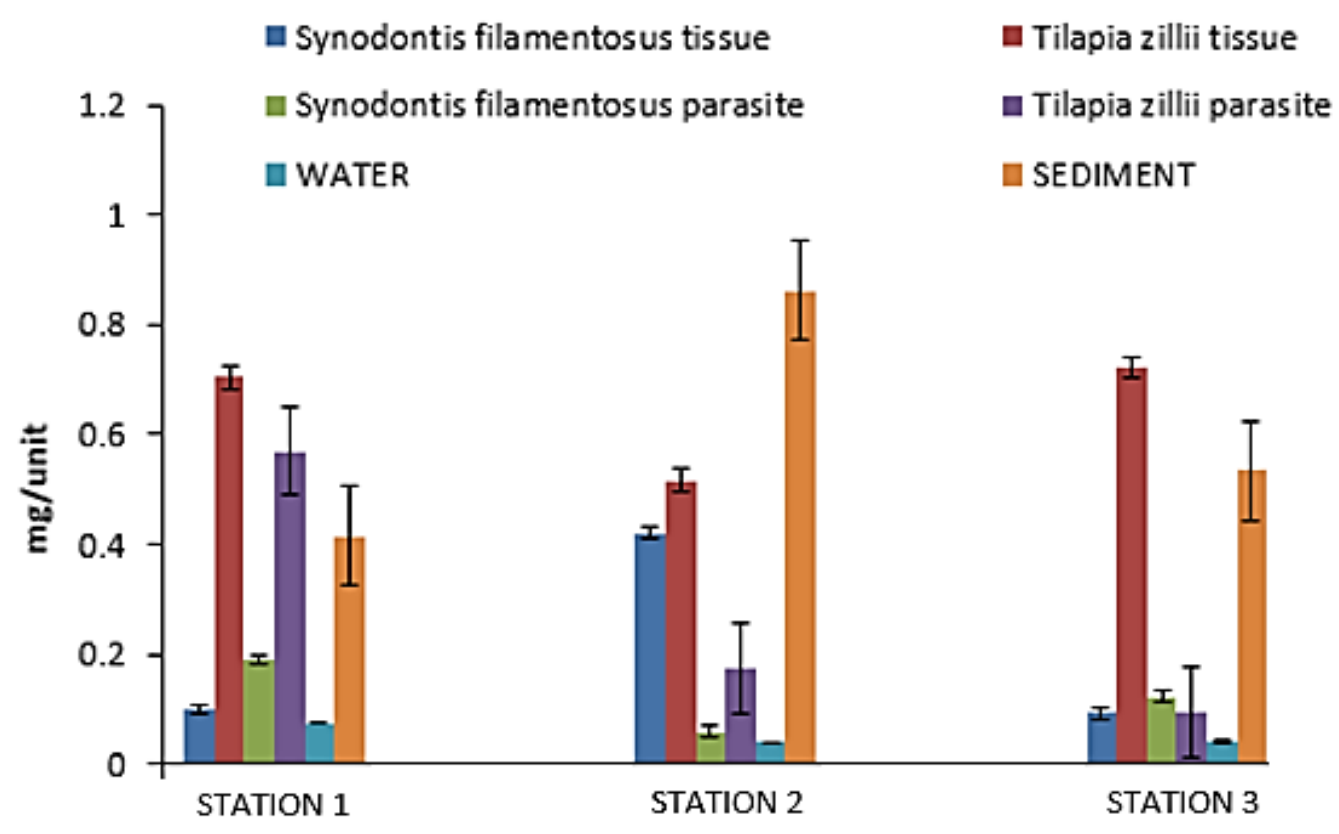

Fig. 8: Comparison of total PCBs in environmental matrices across stations

T. zillii, S. filamentosus, and their parasites all accumulated significant concentrations of PCBs at all the stations. T. zillii exhibited the highest bioaccumulation factor particularly at Station 3.This was accompanied by a significant bioaccumulation factor in the endoparasites of the fish. Some appreciable levels of bioaccumulations were detected in the S. filamentosus; particularly at Station 2. This was however not accompanied by appreciable bioaccumulation levels in the endoparasites (Fig. 9).

Significant biota-soil accumulation factors were detected in T. zillii at Station 1, followed by $S$. filamentosus at the same station. The least significant biota-sediment accumulation factor was observed in T. zillii at Station 3 (Fig. 10). Other biotasediment accumulation factors observed were not significant. 


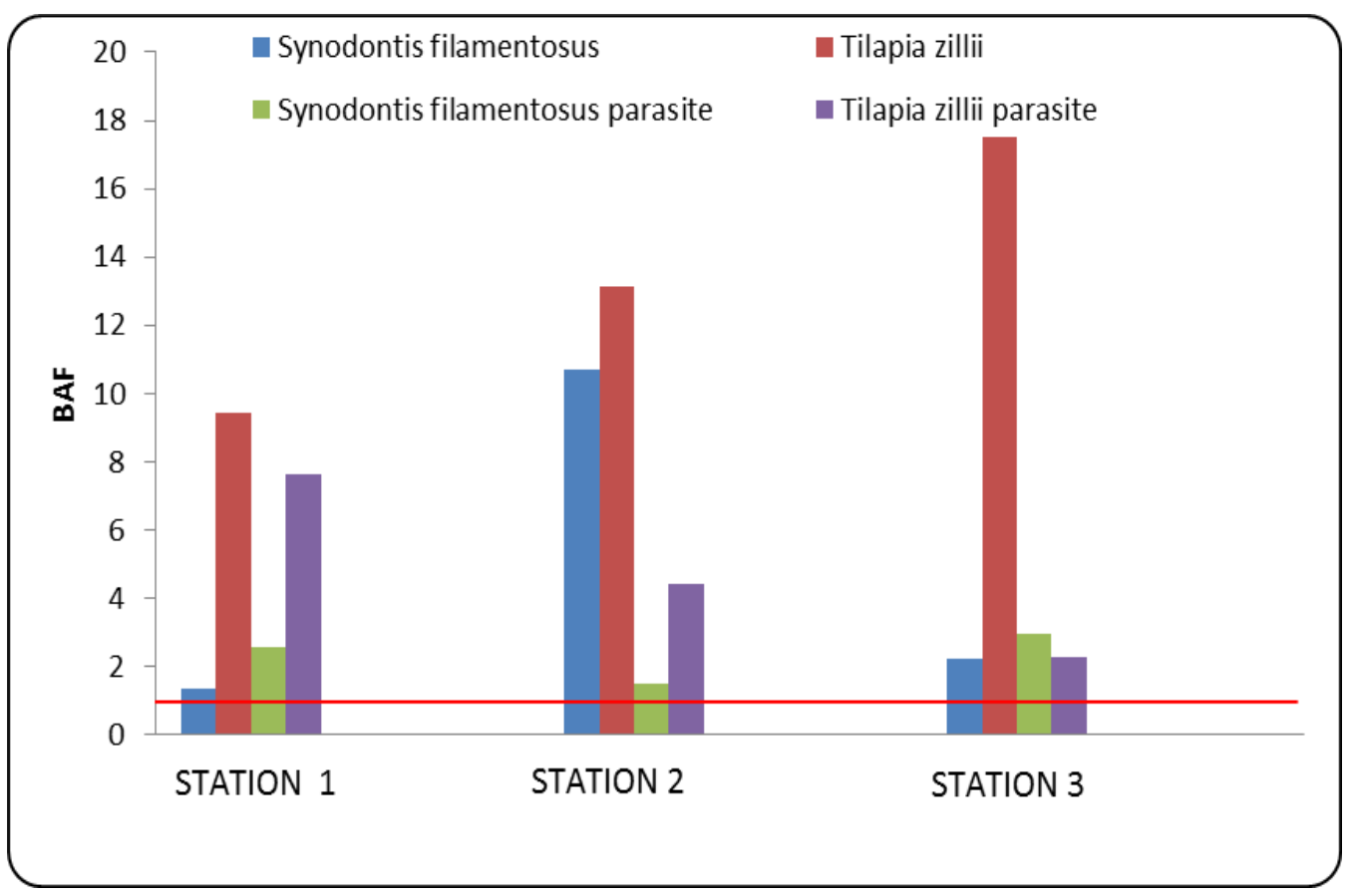

Fig. 9: Bioaccumulation factors (BAFs) of PCBs in biota across stations

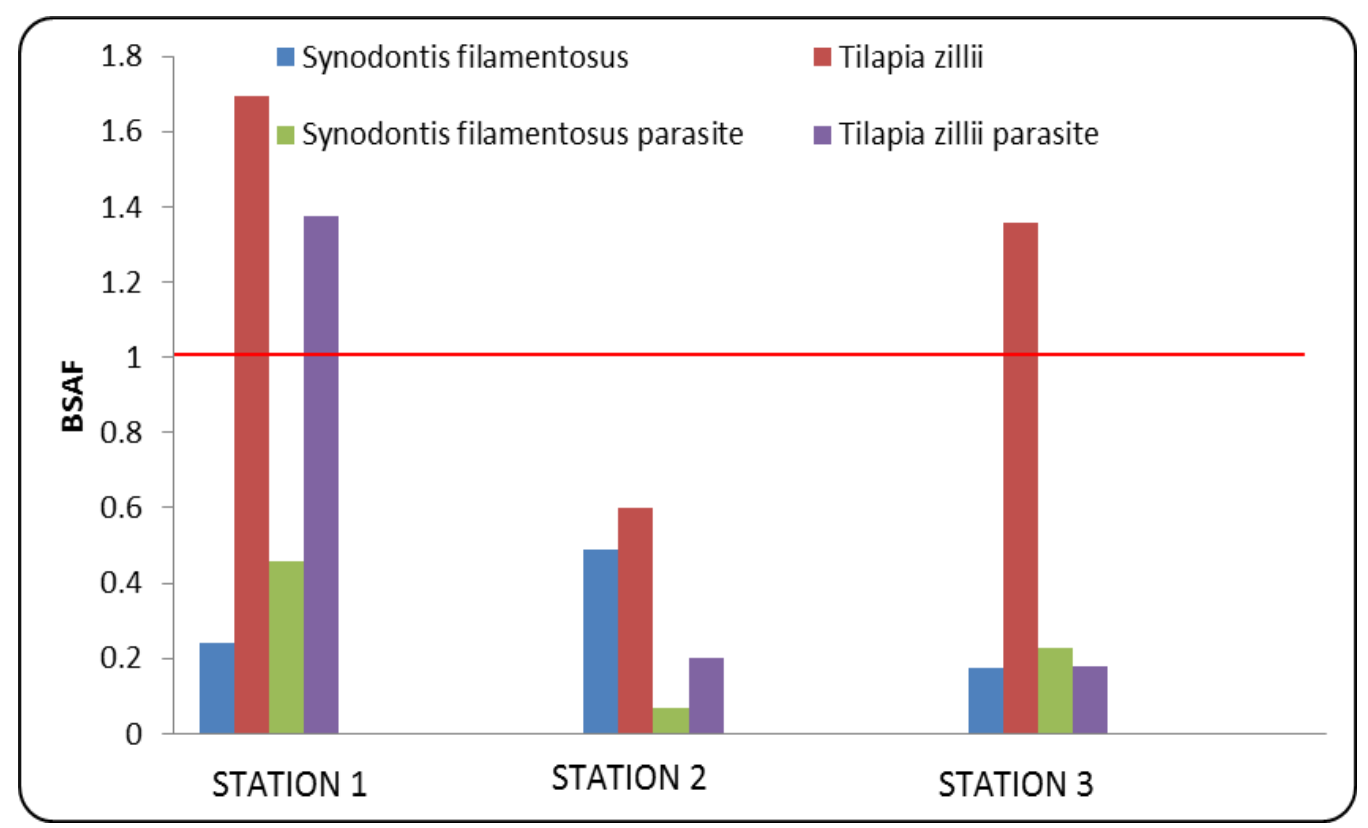

Fig. 10: Biota-soil accumulation factors (BSAFs) of PCBs in biota across stations.

\section{Histopathological analysis}

Microscopic study of the infected intestine and liver eviscerated from both fish speciesrevealed some pathological observations. Intestinal section of T. zillii showed vacoulation and slight degeneration in the lumen (Plate 1: A and B), while the infected intestine of S. filamentosus showed degeneration of the epithelial layer and desquamation of the mucosa (Plate 1: C and D).

Sections of the liver of $T$. zillii shows hyperplasia and desquamation of hepatocytes and epithelial mucosa respectively (Plate 2: A and B), while section of $S$. 
filamentosus liver shows desquamation, hyperplasia and fusion of hepatocytes (Plate 2: C and D).
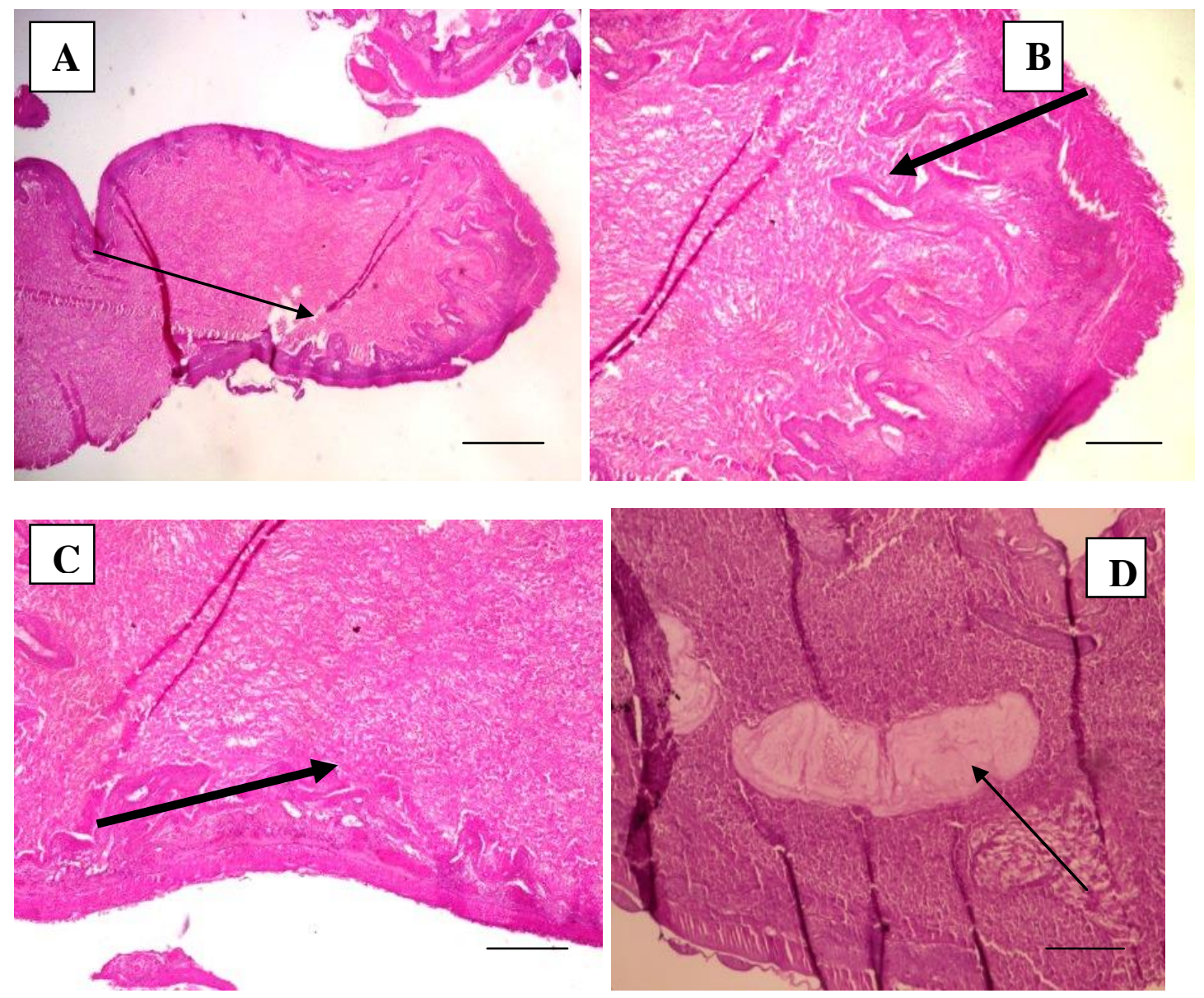

Plate 1: Histopathological section of intestine (Scale bar $=25 \mu \mathrm{m})$

(A and B- T. zillii): Section of the intestinal tissues show vacuolation (thin arrow) and degeneration (thick arrow) in the lumen.

(C and D- S. filamentosus): Section shows degeneration (thin arrow) and desquamation of the epithelial layer of the mucosa (thick arrow).

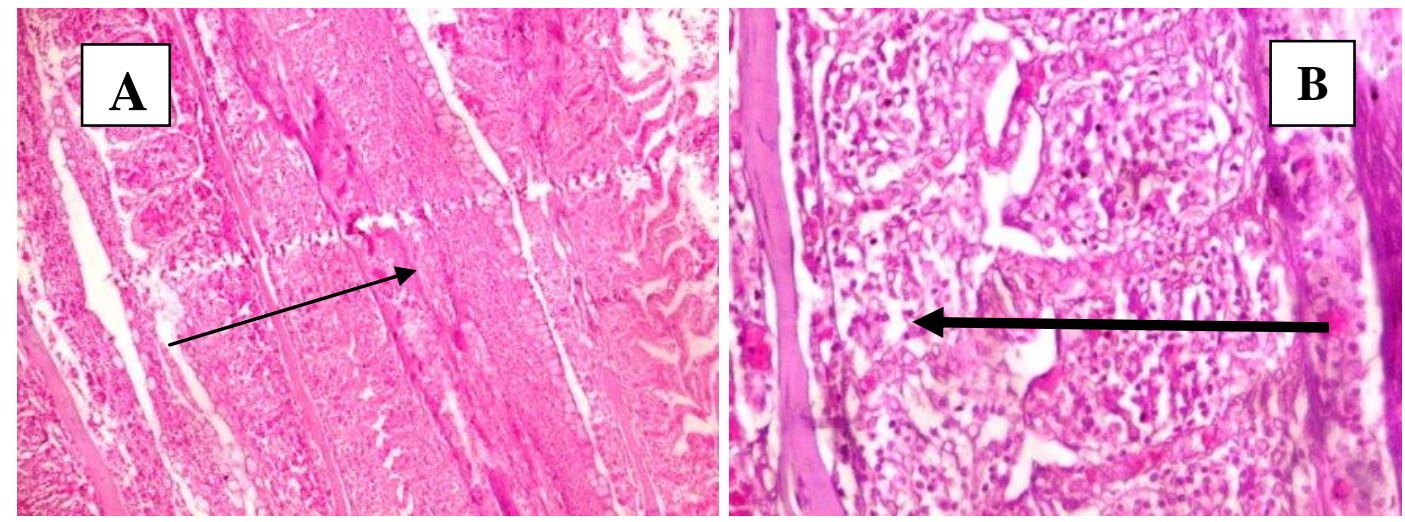




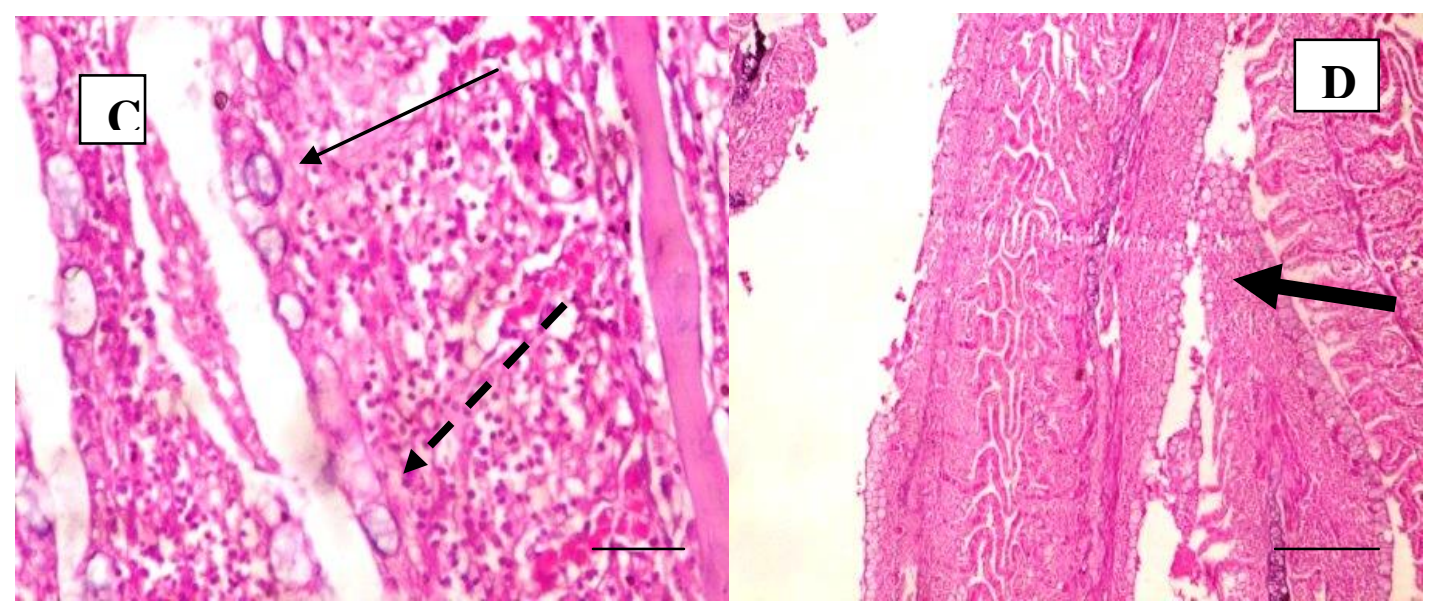

Plate 2: Histopathological section of liver (Scale bar= $25 \mu \mathrm{m})$

(A and B- T. zillii): Sections of the liver show hyperplasia (thin arrow) and desquamation of epithelial (thick arrow).

(C and D- S. filamentosus): Sections of the liver show fusion of hepatocytes (thin arrow), desquamation (thick arrow), and hyperplasia (broken arrow).

Numbers of S. filamentosus which exhibited fusion in the liver and desquamation in the intestine were significantly higher than that of $T$. zillii. While the number of $T$. zillii which exhibited vacuolation in the liver was significantly higher than the observed S. filamentosus. Overall comparative analysis of the respective tissues of both fishes showed that S. filamentosus exhibited significantly greater histopathological alterations than T. zillii (Table 3).

Table 3: Comparative histopathological alterations

\begin{tabular}{lcccc}
\hline $\begin{array}{l}\text { Histopathological } \\
\text { Alterations }\end{array}$ & \multicolumn{2}{c}{$\begin{array}{c}\text { T. zillii affected }(\%) \\
\text { Intestine }\end{array}$} & Liver & \multicolumn{2}{c}{$\begin{array}{c}\text { S. filamentosus affected (\%) } \\
\text { Intestine }\end{array}$} & Liver \\
\hline Hyperplasia & - & 52 & - & 76.5 \\
Fusion & - & - & - & $88.2^{*}$ \\
Degeneration & 82.5 & - & 73.8 & - \\
Desquamation & - & 76.6 & 92.4 & 85.5 \\
Vacuolation & - & $78.2^{*}$ & - & - \\
Total & 160.7 & 128.6 & 166.2 & $250.2^{*}$
\end{tabular}

Asterisked figures are significantly higher $(\mathrm{p}<0.05)$. Sample size $(\mathrm{N})=120$

\section{DISCUSSION}

All physicochemical parameters observed across all stations were within standard regulatory limits, except for Turbidity (10.3 NTU) at Station 1 which was significantly higher than other stations $(\mathrm{p}<0.05)$ and FEPA standard regulatory limit (10 NTU). High TSS and Turbidity levels observed at Station 1 can be attributed to proximity to points of discharge of municipal and industrial wastes.

More severe histopathological injury observed in S. filamentosus than T. zillii is attributable to higher parasitic infections in the former than the latter (Akinsanya et al., 2007; Araneda et al., 2008; Edah et al., 2010). Koponen et al. (2001) earlier observed vacuolation in the liver of feral fish in a PCB-contaminated river. Correlation of current observation with previous indicates that the detected PCBs 
must have been responsible for the vacuolation in the liver of T. zillii in Epe Lagoon. While parasitic infections must have contributed to greater alterations observed in the S. filamentosus (Onyedineke et al., 2010), the extent of damage to the tissues and host nutrient loss are largely dependent on the prevalence of the endoparasites in the hosts. However, prevalence of parasites is greatly influenced by the defense systems of the host fish which is susceptible to PCB toxicity. Therefore, PCB toxicity may cause immunosuppression in the fishthereby enhancing prevalence of the parasites (RosasValdez et al., 2011).

Simultaneous occurrence of nematodes (Procamallanus sp. and Raphidascaroides sp.) and cestode (Wenyonia sp.) in the gastrointestinal tracts of $S$. filamentosus and T. zillii is similar to observations of Akinsanya et al. (2008). Result shows that parasite intensity was length-dependent i.e. the parasite intensity was directly proportional to the weight of the fish individuals. This trend was evident in both males and females of both species. This observation conforms to the observation of de la Cruz et al. (2013) on Nile tilapia.

Higher parasitic prevalence in the male S. filamentosus (68.33\%) compared to its female counterpart (23.33\%), and $11.67 \%$ in the male of T. zillii compared to the female counterparts $(6.67 \%)$ conforms to the higher susceptibility of male fish than females observed by Akinsanya et al. (2008) and Idris et al. (2013). This is attributable to gender-based variability in ecological activities i.e. males are often more active and voracious in search for suitable mates and other ecological resources. In the process, they take in more of the intermediate hosts containing the developing states of parasites than the females (Sagerup et al., 2000; Stahl et al., 2009; Ekanem et al., 2011; Esiest, 2013; Oluoch-Otiego et al., 2016)

Lipophilic organic pollutants such as PCBs in aqueous phase are readily bioconcentrated by aquatic fauna and the rate is species-specific. Depending on the octanol-water partition coefficients, pollutants may reach manifold concentrations in biota, in concentrations higher than the source water. Outstandingly high concentrations of PCB 81 were detected in T. zillii, particularly at Station 1 and 3 (Fig. 3). High concentration of PCB 81 was also detected in the parasite of $T$. zillii Station1 (Fig. 2). This suggests a high bioaccumulation of PCB 81 by the parasites from the host. The presence of PCB congeners in the lagoon can be linked to run-off from industrial sites around the metropolis in the catchment areaThe most PCB congeners were detected in the parasites of S. filamentosus; except PCBs 28, 101 and 153 which were absent in S. filamentosus parasites across the stations (Fig. 4). While only PCB 81 was detected in the host S. filamentosus at Station 2 (Fig. 5). Results show that the endoparasites of S. filamentosus might have inefficiently metabolized the PCBs and the host (S. filamentosus) might have metabolized other PCB congeners, except PCB 81. PCB 81 was also poorly metabolized in the T. zillii and their endoparasites, hence high concentrations of PCB 81 in all the biota analyzed.

The high concentrations of PCB 81 in all biota can be linked to their exceedingly high concentrations in the bottom soil across the stations; with Station 2 exhibiting the highest concentration. However, in the overlying water column the PCB congeners detected were PCB 8 (Station1), PCB 41 (Stations 1 and 2), PCB 77 (all stations), PCB 123 (Station 3), PCB 153 (Stations 2 and 3), and PCB 156 (Station 1). Low concentration of PCB 81 in the water might be as a result of high sorption capacity of the congener in the bottom soil. Results show that the fish might have accidentally ingested high levels of PCB congeners from the bottom soil in the process of foraging. 
A general overview of the profile of PCB accumulation showed that T. zillii, followed by their endoparasites accumulated outstanding concentrations (Figure 8). This is an indication that $T$. zillii may be a more bioaccumulator of PCBs than $S$. filamentosus. However, the toxicant burden of $T$. zillii was appreciably shared by its endoparasites. Furthermore, significant biota-soil accumulation factors observed in the T. zilliii (Stations 1 and 3) and their endoparasites (Station1) support the fact that PCBs had significant sorption capacity into the soil at Stations 1 and 3. The endoparasites of $T$. zillii had accumulated appreciable concentration from its host. Results show evidences of host-to-parasite xenobiotic transfer.

\section{CONCLUSION}

Accumulation of toxicants in parasites is a function of the concentration in the host. The tissue injuries are linkable to both PCB toxicity and parasitic infections. Findings show that $\mathrm{S}$. filamentosus is a better bioindicator of tissue injury while $T$. zillii is a better bioaccumulator.

\section{REFERENCES}

Ademoroti, C. M. O. (1996). Standard methods for water and effluents analysis. Foludex Press Ltd., Ibadan. 3: 29-118.

Adeogun, A.O.; Adedara, I.A. and Farombi, E.O. (2016). Evidence of elevated levels of polychlorinated biphenyl congeners in commonly consumed fish from Eleyele Reservoir, Southwestern Nigeria. Toxicology and industrial health, 32(1): 22-29.

Adeyemi, S.O.; Bankole, N.O.; Adikwu, I.A. and Akombu, P.M. (2009). Food and Feeding Habits of some commercially important fish species in Gbedikere Lake, Bassa, Kogi-State, Nigeria. International Journal of Lakes and Rivers, 2(1): 31-36.

Adite, A.; Megnisse, G. A. H. and Ategbo, J. M. (2017). Reproductive Biology and life history patterns of the claroteid, Chrysichthys nigrodigitatus (Lacepede: 1803) from man-made lake in southern Benin. J. Fish Aquat. Sci., 12: 106- 116.

Akinsanya, B.; Otubanjo, O.A. and Ibidapo, C.A. (2007). Helminth Bioload of Chrysichthys nigrodigitatus Lacepede, 1802) from Lekki Lagoon, Lagos, Nigeria. Turkish Journal of fish Aquaculture Science, 7: 83-87.

Akinsanya, B.; Hassan A.A. and Adeogun, A.O. (2008). Gastrointestinal Helminth Parasites of the fish Synodontis clarias (Siluriformes: Mochokidae) from Lekki lagoon, Lagos, Nigeria, acessed at http://www.biologia. ucr.ac.cr/rbt/ attachments/volumes/vol56-4/ on 26/08/2010

Animesh, R.; Shakhawate, H.; Mohammad, L. R.; Mohammad, A. S. and Mir, M. A. (2014). Fecundity and gonadosomatic index of Glossogobius giuris (Hamilton, 1822) from the Payra River, Patuakhali, Bangladesh. Journal of Fisheries. 2 (2): 141-147.

Araoye, P. A. (2008). Physical factors and their influence on fish species composition in Asa Lake, Ilorin, NigeriaJ. Trop. Biol. 57 (1-2): 167-175.

Araneda, M.; Perez, E.P. and Gasca, L.E. (2008). White shrimp Penaeus vannamei culture in freshwater at three densities: condition state based on length and weight. Aquacultulture, 283: 13-18. 
Berg, M., V.; Kypke, K.; Kotz, A.; Tritscher, A.; Lee, S. Y.; Magulova, K.; Fiedler, H. and Malisch, R. (2017). WHO/UNEP global surveys of PCDDs, PCDFs, PCBs and DDTs in human milk and benefit-risk evaluation of breastfeeding Boulenger, George Albert (1909). Catalogue of the fresh-water fishes of Africa in the British museum (Natural history). London: British Museum. pp. 460-461. Arch Toxicol (2017) 91:83-96 DOI $\quad 10.1007 / \mathrm{s} 00204-016-1802-\mathrm{z}$

Cappelletti, N.; Speranza, E.; Tatone, L.; Astoviza, M.; Migoya, M. C. and Colombo, J. C. (2015). Bioaccumulation of dioxin-like PCBs and PBDEs by detritusfeeding fish in the Rio de la Plata estuary, Argentina.Environmental Science and Pollution Research, 22(9): 7093- 7100.

Chalkia, V.V. and Bobori, D.C. (2006). Length-Length and Length-Mouth Dimensions Relationships of Freshwater Fishes of Northern Greece. Proceedings of the 10th nternational Congress on the Zoogeography and Ecology of Greece and Adjacent Regions pp. 123. Patra, Greece, June 26-30, 2006

Colombo, J.; Cappelletti, N.; Barreda, A.; Migoya, M. C. and Skorupka, C. N. (2005). Vertical fluxes and accumulation of PCBs in coastal sediments of the Río de la Plata estuary, Argentina. Chemosphere, 61:1345-1357.

Cuvier, Georges (1934). The Animal Kingdom Arranged in Conformity with its Organization, Volume 10. Translated by Griffith, Edward. London: Whittaker and Co. p. 406.

Daley, J.; Leadley, T. and Drouillard, K. (2009). Evidence for bioamplification of nine polychlorinated biphenyl (PCB) congeners in yellow perch (Perca flavascens) eggs during incubation. Chemosphere, 75(11): 1500-1505.

de la Cruz, C.P.P.; Bandal, M.Z.; Jr. Avila, A.R.B. and Paller, V.G.V. (2013). Distribution Pattern of Acanthogyrus sp. (Acanthocephala: Quadrigyridae) in Nile Tilapia (Oreochromis Niloticus L.) From Sampaloc Lake, Philippines. Journal of Nature Studies. 12 (1): 1-10

Edah, B.A.; Akande, A.O.; Ayo-Olalusi, C. and Olusola, A. (2010). Computed the wet weight- dry weight relationship of Oreochromis niloticus (Tilapia). International Journal of Food Safety, 12: 109-116.

Ekanem, A.; Peyo, V. O. and Sampson, A. F. (2011). Parasites of landedfish from Great Kwa River, Calabar. International journal of fisheries and aquaculture, 3(12): 225-230.

Esiest, U.L. (2013). Length-weight relationship and parasites of Chrysichthys nigrodigitatus in Cross River Estuary, Itu local government area, Akwa Ibom State, Nigeria. Basic Research Journal of Agricultural Science and Review, pp: 154-165.

Federal Environmental Protection Agency (FEPA) (2003). Guidelines and Standards for Environmental pollution control in Nigeria. Pp 420.

Froese, R., and Pauly, D. (2011). FishBase. World Wide Web electronic publication. URL: $\quad$ www.fishbase.org http//:www.fishbase.org [version 08/2011]

Froese R. and Pauly, D. (2014). FishBase. FishBase. World Wide Web electronic publication. URL: www.fishbase.org http//:www.fishbase.org

Kaoud, H.A. and Eldahshan, A. (2010). Bioaccumulation of cadmium in the fresh water prawn Macrobrachium rosenbergii. Nature and science, 8:4.

Karachle, P.K. and Stergiou, K.I. (2004). Preliminary Results on Relationships between Tail Area and Total Body Length for Four Fish Species. Rapports de la Commission International de la Mer Méditerranée, 37:pp. 376 
Karachle, P.K. and Stergiou, K.I. (2010). Food and Feeding Habits for Eight Fish Species from the North Aegean Sea. Proceedings of the 14thPanhellenic Symposium of Ichthyologists, pp. 7-10, Piraeus, Greece, May 6-9, 2010

Karachle, P.K.. and Stergiou, K.I. (2011). Feeding and Ecomorphology for Seven Flatfishes in the N-NW Aegean Sea (Greece). African Journal of Marine Science, 33(1):67-78.

Karpouzi, V.S. and Stergiou, K.I. (2003). The Relationships between Mouth Size and Shape and Body Length for 18 Species of Marine Fishes and Their Trophic Implications. Journal of Fish Biology, 62:1353-1365, ISSN 1095-8649

Koponen, K.; Myers, M. S.; Ritola, O.; Huuskonen, S. E. and Lindström-Seppä, P. (2001). Histopathology of feral fish from a PCB-contaminated freshwater lake. Pubmed. 30(3):122-126.

Kramer, D.L. and Bryant, M.J. (1995). Intestine Length in the Fishes of a Tropical Stream: 2. Relationships to Diet - the Long and Short of a Convoluted Issue. Environmental Biology of Fishes, 42:129-141, ISSN 0378-1909

Kumolu-Johnson, C. A. and Ndimele, P. E. (2010). Length-Weight Relationships and Condition Factors of Twenty-One Fish Species in Ologe Lagoon, Lagos, Nigeria. Asian Journal of Agricultural Sciences 2(4): 174-179.

Lalèyè, P.; Chikou, A.; Gnohssou, P.; Vandewalle, J.C. and Teugels, G. (2006). Studies on the Biology of two species of catfish Synodontis schall and Synodontis nigrita (Ostariphysi: Mochokidae) from the Ouémé River, Bénin. Belgian Journal of Zoology, 136(2):193- 201.

Livingstone, D.R.; Förlin, L. and George, S.G. (1994). Molecular biomarkers and toxic consequences of impact by organic pollution in aquatic organisms. In: Sutcliffe, D.N. (Ed.), Water Quality and Stress Indicators in Marine and Freshwater Systems: Linking Levels of Organization. Freshwater Biological Association, Ambleside, pp 154-171.

Moore, M.N.; Allen, J.I. and McVeigh, A. (2006). Environmental prognostics: an integrated model supporting lysosomal stress responses as predictive biomarkers of animal health status. Marine Environmental Research, 61: 278-304.

O’Grady, S.P.; Morando, M.; Avila, L. and Dearing, M.D. (2005). Correlating Diet and Digestive Tract Specialization: Examples from the Lizard Family Liolaemidae. Zoology, 108:201-210, ISSN 0944-2006

Okoh, P. M. (2015). Exposure to Organo-Chlorinated Compound PolyChlorinated Biphenyl (PCB), environmental andpublic health Implications: A Nigeria Case study. International Journal of Chemical Studies, 2(6): 1421.

Okoh P. M. and Daniels C. U. (2016). Exploration, Mining and Energy Generation in Nigeria:Exposure to Organo-Chlorinated Compound and Other Chemicals Environmental and Public Health Implications. Modern Environmental Science and Engineering, 2(2): 100-110.

Oluoch-Otiego, J.; Oyoo-Okoth, E.; Kiptoo, K.K..; Chemoiwa, E.J.; Ngugi, C.C.; Simiyu, G. and Opiyo, M.A. (2016). PCBs in fish and their cestode parasites in Lake Victoria. Environmental monitoring and assessment, 188(8): 483.

Osho, E. F.; Ajani, E. K..; Orisasona, O. and Omitoyin, B. O. (2016). Total replacement of fishmeal by soybean meal with or without methionine fortification in the diets of nile tilapia, Oreochromis niloticus. J. Fish. Aquat. Sci., CC: CC-CC. 
Osibanjo, O. B. (1990). Review of chlorinated substance in marine fish and shellfish of Nigeria. Marine pollution bulletin, 21: 581-586.

Onyeidineke, N.E.; Ofoegbu, P.U. and Ukogo, (2010). Helminth Parasites of Some Freshwater Fish from River Niger at Ilushi, Edo State, Nigeria. American Journal of Science, 6(3): 16-21.

Paugy, D. and Roberts, T. R. (2003). Mochokidae. p. 195-268 In C. Lévêque, D. Paugy and GG Teugels (eds.) Fauna of the Freshwater and Brackish Fish of West Africa, Volume 2. Coll. Tropical Fauna and Flora 40. Royal Museum of Central Africa, Tervuren, Belgium, National Naturalle History Museum, Paris, France and Research Institute for Development, Paris, France. 815 p.

Paterson, G.; Jian Liu, G.; Haffner, D. and Drouillard, K. G. (2010). Contribution of Fecal Egestion to the Whole Body Elimination of Polychlorinated Biphenyls by Japanese Koi (Cyprinus carpio) Environmental Science \& Technology 201044 (15), 5769-5774 DOI: 10.1021/es903348z

Peck, H.E.; Costa, D.P. and Crocker, D.E. (2015). Body reserves influence allocation to immune responses in capital breeding female northern elephant seals. Functional Ecology, 30(3): $\quad$ 389-397

Rosas-Valdez, R. and de Leon, G. P. (2017). Patterns of Host Specificity Among the Helminth Parasite Fauna of Freshwater Siluriforms: Testing the Biogeographical Core Parasite Fauna Hypothesis. J. Parasitol, 97(2): 361-363.

Sagerup, K..; Henriksen, E.O.; Skorping, A.; Skaare, J.U. and Gabrielsen, G.W. (2000). Intensity of parasitic nematodes increases with organochlorine levels in the glaucous gull. Journal of Applied Ecology, 37(3): 532539.

Spataru, P. (1978). Food and Feeding Habits of Tilapi zillii (Gervais) (Cichlidae) in Lake Kinneret. Aquaculture, 14:327-338.

Stahl, L.L.; Snyder, B.D.; Olsen, A.R. and Pitt, J.L. (2009). Contaminants in fish tissue from US lakes and reservoirs: a national probabilistic study. Environmental Monitoring and Assessment, 150(1-4): 3-19.

Sures, B.; Siddall, R. and Taraschewski, H. (1999). Parasites as accumulation indicators of heavy metal pollution. Parasitology Today, 50: 16-21.

Sures, B. (2007). Host-parasite interactions from an ecotoxicological perspective. Parassitologia, 49:173-176.

Wainwright, P.C. and Richard, B.A. (1995). Predicting Patterns of Prey Use from Morphology of Fishes. Environmental Biology of Fishes, 44:97-113, ISSN 0378-1909

Wang, W.X. (2002): Interaction of trace metals and different marine food chains. Marine Ecology Programme Service, 243: 295-309.

Williams, C. and Bonner, T.H. 2008. Texas Freshwater Fishes: Tilapia zillii Redbelly Tilapia. Texas State University - San Marcos, Biology Department, Aquatic Station.

Wootton, R.J. (1998). Ecology of teleost fishes. 2nd Edition. Kluwer Academic Publishers, ISBN 0-412-64200-X, Fish and Fisheries Series 24, London

Xing, Y.; Lu, Y.; Dawson, R. W.; Shi, Y.; Zhang, H. and Wang, T. (2005). A spatial temporal assessment of pollution from PCBs in China. Chemosphere, 60:731-739. 